\title{
Regenerative Documentary: Posthuman Art in the Context of the Philippine Drug War Adjani Guerrero Arumpac
}

Regenerative documentary is generated by a composite unity that comprises the living system of resistance in the Philippines. It takes into account the contingent, illustrated by artist groupsRespond and Break the Silence over the Killings (RESBAK), Sandata, and Gantala Press-that converged with the living system of resistance where and when human rights was curtailed by an environment of impunity, systemic poverty, social inequality, and injustice. The purpose of regenerative documentary is to identify and make known that a system of resistance exists and it is living. By harnessing the ideas of narrative, emergence, and ethicality espoused by autopoiesis and critical posthumanism, regenerative documentary situates its expediency within the context of the Philippine human rights violations under the Duterte regime as a transformative critical posthuman art.

Keywords: Documentary, critical posthumanism, autopoiesis, Philippine drug war, contingency

On March 17, 2020, the Philippine government implemented a lockdown in cities within its jurisdiction hit hardest by the COVID-19 pandemic (Office of the President, 2020). To mitigate the spreading of the novel coronavirus, all forms of activities involving physical congregation were put to a halt. Schools, businesses, and theaters were shut down and scheduled events were cancelled. A day pior to the lockdown was the supposed launching of a pioneering documentary festival celebrating a hundred years of documentary tradition in the Philippines. Daang Dokyu was planned to be a five-day affair celebrating the marginalized cinematic form through a series of screenings and discussions of traditional film and video documentaries (Limos, 2020). Daily curated sessions were grouped under a chosen theme, the final one being the "future." The festival curatorial notes posed a question to ease the audience into the premise of the section: "What roles does technology in this rapidly evolving information age play in the kinds of documentaries being produced?" (FILDocs, Inc., 2020, p. 53) This study cogitates on the inquiry presented by the disrupted documentary festival that pertains to a 
speculative emergent documentary form - a problematic conveniently and unfortunately made urgent by limitations set by the pandemic. It takes into account the various strands of development that converged into the current Philippine documentary context-namely documentary, technology, and society-to propose a new documentary form hereinafter referred to as "regenerative documentary." To understand what regenerative documentary can be, the question I primarily pose is not how it will be made but how to see it as thus.

The recent phenomenon of documentary as an increasingly female stronghold invites a critical inquiry. ${ }^{1}$ In an interview with women documentarists (O'Falt, 2016), notions of documentary as female expertise were either attributed to the genre (1) as an alternative space kinder to women because it has fewer gatekeepers due to smaller funding; and/or (2) as a communicative practice based on compassion and sensitivity, with both characteristics assumed to be inherently female. These are variations of the immanent marginality of both documentary and woman. In a bid to widen the discourse on women and documentary, this study uses the lens of posthumanism. Posthuman sees beyond identity politics that have defined as well as overdetermined woman. Certainly, women in documentary thrive through a struggle that, according to Donna Haraway (1991), is based on "seizing the tools to mark the world that marked them as other" (p. 175).

In a survey of 550 documentary industry professionals across the globe, $66 \%$ were female, $58 \%$ saw themselves as social issue advocate filmmakers, 95\% made linear documentaries, 57\% distributed their documentaries in film festival, and $44 \%$ distributed their works in grassroots and community screenings (Chattoo \& Harder, 2018). These numbers tell my story. As posthuman feminists feel obliged to position their subjectivities, I situate the "I" in this essay as a female documentarist from the Philippines. My body of linear narrative digital documentaries represents the struggles of marginalized Filipinos. I speak from this locatedness and this informs my subjectivity. Acknowledging that posthumanism is a concept wrought from Western experience, the theoretical underpinning that underlines the logic of regenerative documentary adopts critical posthumanism forwarded by Rosi Braidotti (2019) in order to situate it in the local context.

Gender likewise defines the parameters that informed the personal seeking for a new documentary form. From 2005 to 2015, the body of work I produced was comprised of traditional full-length documentary videos exploring the variegated manifestations of systemic oppressive working and living conditions in the country. However, a gradual shift in style started in 2016, when childbirth and child-rearing coincided with the start of the new Philippine president Rodrigo Duterte's campaign against illegal 
drugs. Negotiating time and focus among domesticity, video production, and the gravity of state-sanctioned human rights violations, the works I produced since 2016 took on the form of viral videos produced as a member of Respond and Break the Silence Against the Killings (RESBAK, n.d.). RESBAK is an interdisciplinary alliance of artists, media practitioners, and cultural workers. We produced short videos that were uploaded online as part of an information and awareness campaign against drug war impunity. The whole creative process was a deviation from my prior documentary practice built upon community immersions to record the quotidian.

Nevertheless, four years of concerted efforts of RESBAK, along with various human rights groups initiatives, did not make a dent in the current regime's popularity. Instead, the same course of state action is being used to address the COVID-19 pandemic. The official drug war kill list accounts for over 8,000 deaths (United Nations High Commissioner for Human Rights, 2020). The unaccounted death estimate suggests more than twice this figure (Coronel, Padilla, \& Mora, 2019). Meanwhile, despite more than a hundred days of lockdown, the longest in the world, COVID-19 viral infection has only escalated, making the Philippines the country with the fastest rising cases of infection in the Western Pacific (Lee-Brago, 2020). To quell brewing unrest, the Anti-Terrorism Law was signed nearly fifteen weeks after the lockdown (Esguerra, 2020). The overreaching counterterrorism measure endeavors to penalize any form of "terroristic" act, including inciting to sedition.

Thus, locked down by the virus and state forces weaponized against its critics, the challenge for advocacy documentary production in the time of pandemic and social media-fuelled populism is to assess where transformations can be made. In trying to make sense of the myriad areas of study that this research encompasses, autopoiesis was harnessed as the epistemological, adopting its original definition in biologists Humberto Maturana and Francisco Varela's (1928) study of cellular life. Autopoiesis refers to the essential characteristic of autonomy in a living system that is sustained through continuous regeneration of its network of processes. This research establishes regenerative documentary as the cognition of an autopoietic living system as it interacts and transforms with its environment. Through this primary definition, regenerative documentary resolves its characterisation beyond representational cinematic aesthetics.

A reorientation of one's perspective of advocacy documentary can prove vital in identifying the potential of moving image to provide agency where needed while making sense of the chaos of our technology-driven times. To be able to see thus entails a more comprehensive overview of the basic doctrines of technology and documentary that emanated from the West. By 
reviewing the core philosophies brought about by the eras that bore these foundational ideas, we are able to map, as well, their transformations over time and through this, glean their pitfalls and promises in the Philippine context.

\section{Posthuman and Autopoiesis}

Posthuman art is a tautology. Haraway (1991) defined posthuman as a "blasphemous cyborg" (p. 149), a construct created where the boundary between human, machine, and animal dissolved. This cyborg was conjured within the chaos of progressive American socialism and feminism, fragmented by various political identifications within. Rife with divisions that limited genuine proactivity, Haraway prescribed affinity instead of identity so as to be able to transcend bigotry and connect with others. The others, according to Braidotti (Yale University, 2017), is the sum of all not represented by the Vitruvian Man-women, animals, nature, etc. The Enlightened Man is the "index of access to power," who birthed reason that has the ability to rationalize even wars and injustices. For Braidotti (Yale University, 2017), the posthuman is a tool with which to explore the alleyways of emergent agencies in the crumbling kingdom of liberal humanism. The human is the center that cannot hold. Within this paradigm, the turn to the informational and virtual became a logical means to willpower (Hayles, 1999). ${ }^{2}$ The deployment of the posthuman - as myth, tool, and conditionpieced together the prefix "post-" not as a temporal continuity of what comes after human. It is a resetting. Unburdened by the ontology of rationality that has repeatedly failed mankind, the "post-" thoroughly shattered the overdetermined human to unfetter alternative possibilities of vitality.

In his book Technics and Time, 1: The Fault of Epimetheus, Bernard Stiegler (1998) redefined technology by differentiating it from Martin Heidegger's (1977) concept of technology as a human tool for "revealing" (p. 18) nature as raw material for exploitation. Stiegler (1998) exhumed the etymology of technology, tekhne, by retelling the myth of Prometheus who stole fire from the gods to bestow upon and warm naked humanity. In his version of the myth, divine fire was the first tekhnē or prosthesis that compensated for the originary incompleteness of humans. Humans were incomplete due to Prometheus's brother, Epimetheus, who made the mistake of giving all qualities to animals and left none for the humans. By refocusing the tale to the fire that completed the human, Stiegler reinstated tekhnē alongside epistēmē or knowledge/understanding as the birth of humanity. Therefore, anthropogenesis or the process of becoming human is inevitably tied to technogenesis or the co-evolution of human with tools/ technology. Man had to become through tekhnē because of divine "wisdom 
that is incomplete" (1998, p. 195). This blasphemy was the fertile ground upon which the Enlightenment flourished-the gods are as flawed as the lacking human they created. Through centuries, tekhnē has evolved to mean "art," denoting creativity as the endless struggle of man to negotiate being.

This study infers that both prefix (post-) and modificand (art) in posthumanart pertain to theimmanence of technicity in human. However, the metanarrative that Haraway, Braidotti, and Hayles struggled to escape from through the "post-" was reified by Stiegler's reconception of "tekhne"/"art." Stiegler went back in time to harness the mythological espoused by the very institution of liberal humanism that feminist posthumanists tried to break free from. The paradoxical tautological intrinsic in posthuman art is a critical tension that informs discussions of documentary practices in this essay. The first step is to determine whether the human, as the index of "post-" and "art" in posthuman art, should be iterated or negated by the twin opposing forces of originary technicity. Within such a quandary, how does posthuman art as documentary look like?

The posthuman is a situated subjectivity. N. Katherine Hayles (1999) stated that the posthuman is not "a universal human condition" and "in fact it affects only a small fraction of the world's population" (p. 6). In her book How We Became Posthuman, Hayles (1999) primarily elucidated on posthumanism through an extended discussion of the foundational concepts of modern cybernetics tradition. The first-wave cybernetics was led by American mathematician Norbert Wiener who, along with neurophysiologist Warren McCulloch, mathematician Claude Shannon, and computer scientist John von Neumann, embarked on scientific inquiries on the interrelated concepts of control and communication during a time when the theory of information was beginning to gain critical traction (Hayles, 1999). Through observations made from collective transdisciplinary effort, Wiener (1948) deduced that a system maintains control, or homeostasis, despite erratic environment through information that enables the system to discern and automatically reject changes. Through this postulation of a similarity of processes among human, animals, and machines, Wiener (as cited by Hayles, 1999) mapped the pioneering philosophy of modern cybernetics that synthesized the "organic and mechanical" (p. 8) through the informational. Wiener was a depressive mathematician who saw emotional turmoil as an "unsolved scientific problem" (Hayles, 1999, p. 92). Psychological homeostasis through mathematics became a source of comfort. The turn to the logic of information was seen primarily as a means to assist where the human cannot apprehend. Wiener's (1947) allegiance to the plight of the distressed human was such that he wrote the article "A Scientist Rebels" after World War II. Seeing how their findings contributed 
to the war machinery, he called for members of the scientific community to assess the ethical repercussions of their work. Hayles (1999) drew attention to Weiner's view of cybernetics aligned with liberal humanism. She concluded that the point of first-wave cybernetics "was less to show that man was a machine than to demonstrate that a machine could function like a man" (Hayles, 1999, p. 7).

Nevertheless, the overarching idea of homeostasis could not discount the fact that a feedback loop introduced what Hayles (1999) called as reflexivity. She defined reflexivity as a movement "whereby that which has been used to generate a system is made, through a changed perspective, to become part of the system it generates" (Hayles, 1999, p. 8). This reflexivity is at the core of the second-wave cybernetics developed through Maturana and Varela's (1929) autopoiesis or the study of self-sustaining and self-reproducing closed systems. Strictly speaking, autopoiesis was hypothesized based on direct observations of living cells "and is concerned with the various processes connected with life, such as the interaction with the environment, evolution, and 'cognition"' (Luisi, 2003). Autopoiesis, coined after "auto" or self and "poiesis" or creation (Maturana \& Varela, 1928, p. xvii), is a biological study that aimed to answer the question: What is life? It established that a system is living if and when it remained autonomous despite necessary interactions with its environment.

The perceived paradox of openness (or reflexivity) in a closed homeostatic system is a point of contention comprising the fundamental characteristic of autopoiesis that differentiated it from the closed circularity of cybernetics. To delineate how a living system maintains its autonomy, Maturana (1978) identified two distinctions: the organization, that "refers to the relations between components that define and specify a system as a composite unity of a particular class" (p. 32); and the structure, that "refers to the actual components and the actual relations that these must satisfy in their participation in the constitution of a given composite unity" (p32). Transformations happen at the structural level. Hence, autopoietic systems are "organisationally closed but interactively (or structurally) open" (Mingers, 2006, p. 44).

The openness of autopoiesis allowed other fields to utilize its epistemology for understanding real world phenomena. Consequently, autopoiesis has been categorized under the tradition of general systems theory, an interdisciplinary branch of study that focuses on mapping and understanding complexities across different domains of knowledge through applied systems thinking (Mingers, 2006). But the migration of the theory from biology to the social sciences posed a challenge. In cellular life, the structural changes are triggered at the membrane where the wholeness of 
the cellular components meets the external environment. Whereas in a society, there are no hard-set rules as to what constitutes the parameters of a system (Mingers, 2006).

Niklas Luhmann (2013) assumed this hypothetical as the boundary in his theory of society as a functionally differentiated system. In his social systems theory, closed systems generate communication specific to the living system. Accordingly, these closed communication systems make up the society, creating separate spheres of specialist realities or expert knowledge (e.g., law, governance, etc.) actualized as communication between people. In essence, society is composed of only differentiated communications that cultivate cultures within and interact across boundaries.

Information systems theorist John Mingers (2006) questioned the basic assumption of boundary as an intrinsic characteristic of systems. In his sweeping comparative studies of systems literature, he concluded that "many books do not even index the term, and most others refer to it only in a cursory fashion" (p. 65). The postulation that difference embodied by boundary distinguishes system from the environment is a prevalent notion and it is to this interpretation of autopoiesis by social systems theory that critiques are fielded at. ${ }^{3}$

Notwithstanding ongoing debates and revisions of autopoiesis (Hayles, 1999), this study focuses on the vital feature of autopoiesis that foregrounds all its processes. Maturana and Varela (1928) stated that the autopoietic entity is comprised of what the observer sees as a unity of components. The wholeness of a system is contingent upon the observer's description of it as thus. This logic was informed by the study itself of structural interactions in the cellular membrane. Accordingly, "the domain of all the interactions in which an autopoietic system can enter without loss of identity is its cognitive domain" (p. 119). Essentially, an autopoietic system is maintained by cognition or the knowledge it gains through interaction, embodied as a sequence of descriptions that constitutes its ontogeny. This puts forward that absolute knowledge is not possible as "validation of all possible relative knowledge is attained through successful autopoiesis" (p. 119). Ultimately, autopoiesis denies knowledge of its ontological existence and categorically defines it as situated and phenomenological (Mingers, 2006). It is at this juncture that posthumanism converged with autopoiesis, despite coming from different identifications.

\section{Woman and Narrative}

All of the foundational modern cybernetics queries were presented and contested in the Macy Conferences on Cybernetics from 1943 to 1954 (Josiah Macy Jr. Foundation, 1955). These were transcribed by a lone woman, 
Janey Freed, who until Hayles's book (1999), was unrecognized. Freed's diligent work of translating the auditor $y^{4}$ to written language was arguably a large part of the material foundation of the persistence of the cybernetics tradition, enabling its circulation by making available the documentation of the discussions (Hayles, 1999). Hayles's recognition of Freed was commensurate to her backhanded compliment to the cyberneticists who were, citing Dorothy Smith, "prone to decontextualization and reification because they are in a position to command the labors of others" (p. 82). Freed, as a marginal female worker, became illustrative of the twopronged-biological reproduction and Marxist production-ontology of women's labor. Haraway (1991) inferred that this binary emphasized the "daily responsibility of real women to build unities, rather than to naturalize them" (p. 158). For Haraway, dailiness was an idea peddled by feminism through the struggle of conciliation as unacknowledged female mandate. This ontologized dailiness to life/birthing. To unburden the female, she instead prescribed regeneration. Regeneration is borne of trauma. As Haraway (1991) put it: "We have all been injured, profoundly. We require regeneration, not rebirth, and the possibilities for our reconstitution include the utopian dream of the hope for a monstrous world without gender" (p. 181).

In an effort to reconcile the concept of dailiness and autopoeisis, the materiality of systems already in place that need to be transcended must be acknowledged. This study redefines dailiness as an autopoietic regenerative process through narrativizing. Echoing the concept of narrative as cognition attained through cellular membrane interaction in autopoiesis, dailiness is a relational and navigational tool informing negotiations at the boundary of life and emergences. Dailiness is narrative. Narrative comprises the personal as revelational that the Macy Conferences cybernetics thinkers relegated as unquantifiable subjectivity. Dailiness is reflexivity suppressed by rigid empirical epistemology so as to maintain the scientific legitimacy of modern cybernetics. Hayles's (1999) account of the Macy Conferences revealed that it was within this context of wariness of the incomputable that the human became disembodied in favor of information. Manageable disembodied information is a construct of equilibrium informed by the neuroses of leading male cybernetics thinkers. Hayles asserted the need to break away from this binary, where human and information are opposing poles. However, only six years after her statement, Hayles (2005) acknowledged that the rapid evolution of posthumanism in a short interval has rendered the human/information binary outdated.

Indeed, the evolving posthuman complexities obligate a constant weaving to produce unities. And the tenacity in sieving through the 
quotidian for harmonies is gendered. The future has always been white and male, "because white males have the ability to offer the most optimistic vision" (Eleveth, 2015, para. 12) due to the fact that they do not have to encounter the everyday issues and problems that women face. Hannah Arendt (1998) located this male privilege in the worldly human condition of work, where scientists act from the perspective of the cosmos and not into the human interrelationships. She deplored this condition that led into the absence of stories and histories that comprise the essence of human existence. Dailiness is located in the Arendtian narrative that differentiated itself from male professional thinking. Julia Kristeva (2001), expounding on Arendt's thoughts, wrote that narrative "grounds human life in what is specific to it, in what is non-animal about it, non-physiological" (p. 8).

Therefore, it came as no surprise that women posthuman philosophers felt the need to tell their stories first. Albeit, the confessionals were usually accompanied with disclaimers of discomfort. In Writing Machines, Hayles (2002) first situated herself as a member of a community of writers, theorists, and academics to show her position in discussing inscription technologies. Doing so, she lamented being "an autobiographer almost against my will" (p. 10). Haraway (1991) was also self-conscious and self-deprecatory in her statement: "I have a body and mind as much constructed by the postSecond World War arms race and Cold War as by the women's movements" (p. 173). In her book Minimal Ethics for the Anthropocene, Joanna Zylinska (2014) had to substantiate "the reluctant yet also sometimes inevitable use of the pronoun ' $\mathrm{I}$ ' ... and the multiple paradoxes implied in any attempt on the part of a singular female human writer to author a post-anthropocentric ethics" (pp. 16-17). The gendered propensity to perform dailiness through revealing one's subjectivity is the turn to ethical. Zylinska prescribed minimal ethics as the acknowledgment of entanglement of the human with an evolving world. Narrative is active and engages the human condition of plurality or the acknowledgment and the consequent interrelation with others. This performativity translates to responsibility and becomes a framework for seeing "ways of becoming better in the world" (p. 93).

\section{Finite Autopoietic Living Documentary}

By establishing narrative as minimal ethics, posthuman cyberfeminists laid down two parameters: the (1) dissolution of material boundaries to open possibilities for wider interrelationships and (2) storytelling as ethical human responsibility to action. Here, the paradox of the tautological posthuman art, defined as the struggle to keep or exclude the human, is brought up again. Who or what is going to tell the narrative of the posthuman? Is the rational human, in a posthuman paradigm, still a believable narrator? This question is 
tailor-fitted to the practice of documentary. While fiction films are also forms of storytelling, it is documentary that mainly problematizes the position of the teller of the story by virtue of the form's claim to representing truth. The concept of reality in documentary has been comprehensively discussed in Bill Nichol's Representing Reality (1991), Brian Winston's Claiming the Real (1995), Kevin Macdonald and Mark Cousins's Imagining Reality (1998), and Paul Ward's The Margins of Reality (2006), among others. Conversely, reflecting on documentary through the framework of posthumanism without rational ontology frees it from the burden of its form declared by John Grierson (1933) as the "creative treatment of actuality" (p. 8). Indeed, the uneasy comfort of viewing "reality" in a linear narrative on a one-way setup is a normative perspective that could not hold. In the same way that cybernetics needed to be opened to transformational external active engagement as autopoiesis, documentary as storytelling that engages reality also had to be reconfigured to accommodate the changing social, political, and technological dynamics of the times it claims to represent.

An observed material transformation in documentary was the shift of focus to the observer. For example, Jean Rouch and Edgar Morin's Chronicle of a Summer (Dauman \& Morin, 1961) showed how the subjects were made to watch themselves and react to how they were represented by the filmmakers. The film illustrated the tension and richness provided by feedback loop. However, technologies such as the computer and the internet introduced new possibilities of enlarging the range of circularity. Although this time, the observer is not just a passive audience but instead an interactive user. Media theorist Lev Manovich (1999) described the landscape of change:

Indeed, if after the death of God (Nietzsche), the end of grand Narratives of Enlightenment (Lyotard) and the arrival of the web (Tim Berners-Lee), the world appears to us as an endless and unstructured collection of images, texts, and other data records, it is only appropriate that we will be moved to model it as a database (p. 81).

Patricia Nogueira (2017) likened the internet database to an "overgrown Borgesian map of human lives, a database without a hierarchy of values nor a comprehensive organization" (p. 156). The fragmentary nature of the online database came from the ontology of information as a function of generality. To create an efficient model of signal transmission with the least inaccuracies (Shannon, 1948), information had to be divested of meaning (Shannon, 1948; Weaver, 1953). Instead of narrative, database is the "new 
symbolic form of the modern age" (Manovich, 1999, p. 81).

The new forms of documentary latched on to the modularity of the database. Modularity is the ability to be constructed by virtue of an original fragmentary nature. These include the interactive documentaries (Choi, 2009; Cucinelli et al., 2018; Galloway et al., 2007; Goodnow, 2004), docugames (Raessens, 2006) and new media documentaries (Castells, 2010). Interactive documentaries are defined not by their digital form nor their documentary function. They became through "the fact of documenting through interactivity" (Gaudenzi, 2013, p. 69) and are considered autopoietic systems that interact with the user as another autopoietic system. In the process, both evolve. Sandra Gaudenzi (2013) proposed to call this autopoiesis "Living Documentary" where documentary became a living entity and the user, a computational interface-each feeding on the other's interactivity.

But this setup is as finite as the technology that contains it. The interactive documentary is still a curated structure. The nonlinear promise of interactivity does not translate to autonomy of the user because "authorial intention is the key element that sustains the interactive documentary as a consistent artwork" (Nogueira, 2017, p. 162). Participatory documentaries have so far not provided agencies for interactivity as a genuine feedback loop due to limitation of user participation to unilateral provision of content (Gaudenzi, 2013) and the inevitable phasing out of technologies that contain these interactive documentaries.

All of these malfunctions were predetermined and point back to the limitation of modularity. Modularity is a part of the open and collaborative computer community standards espoused by manifestos such as the Unix Philosophy that encouraged for software to be simple, modular, and open (The Linux Information Project, 2006). Similarly, Free Software Movement advocated for open and collaborative software platforms to recognize the autonomy of every user (GNU, 2018). However, proprietary technology companies overrode these values under what has been called the "Californian Ideology" (Barbrook \& Cameron, 1996). Californian Ideology refers to the marketization trend of the Silicon Valley community of computer scientists and programmers that originally thrived on the share economy. Free Software Movement founder Richard Stallman (2015) attributed the problem to the intrinsic crisis in proprietary open-source software whose objective is ownership, market infiltration, and revenue. Openness ends where capitalism makes a claim. Hence, it was only logical for Gaudenzi (2013) to conclude that openness was not the primary barometer of success in Living Documentary "but rather what levels and kinds of transformation it affords" (p. 252). 


\section{Minimal Ethics and the Emic Narrative}

Transformation is aspirational for documentary and woman. The tendency to narrativize dailiness is the struggle for emergence from assigned gendered and formal determinations. And so, woman and documentary converge at their co-emergences in the twenty-first century societies mediated by rapidly evolving technologies. The phenomenon of women documentarists is a structural coupling ${ }^{5}$ not found on identity but instead, transformation. Unfortunately, what has been mapped in the discussion of documentary, with Living Documentary as its most recent iteration, is a dead-end. Nevertheless, as Hayles (2005) concluded her posthuman book trilogy: "As is always the case where dynamical emergences are involved, at the end we begin again" (p. 243). The turn to ethicality is the point of resetting documentary as posthuman art. Sifting through ethicality as a means to action used by animal and ecological activists, Zylinska (2014) teasingly conjured the Porsche, as representation of the city and as the locus of her ethical cyborgian hypothesis "for whom philosophizing, storytelling and art-making function as inevitable technical prostheses for a human engaged in the theorization of matter" (p. 136). In effect, minimal ethicsthat acknowledges one's values does not necessarily hold true nor respect the others'-considers "anything else" (p. 136).

To this end of considering anything else, I bring up an emic account of what constitutes the ethical posthuman art as an advocacy documentarist in the Philippines. Situating posthumanism in the local context entails widening the scope of the formative milieu it disowns in order to locate my subjectivity. The Philippines has a fraught history of centuries of Spanish colonization, followed by American occupation (Constantino \& Constantino, 1975, 1978). In this context, the dissolution of the human, created in the mold of Western man, likewise absolves the Western colonizer from the sins of its past that rationalized wars among nations, including massive plundering of natural wealth in the colonies. Hence, directly adopting the posthuman to the context of formerly colonized developing nations commits epistemic violence (Spivak, 1993).

Braidotti (2019) addressed this critique through acknowledgment that posthumanism is only a partial figuration. "It does not define the new human condition, but offers a spectrum through which we can capture the complexity of ongoing processes of subject formation" (p. 36). At this point, the two research questions posed earlier on the form of posthuman art as documentary-how it would look and who could tell it—can be categorically answered. Braidotti's (2019) critical apprisal of posthumanism established its contronymity. This discursive capacity to both enable and debilitate critical undertakings is a condition that necessitates mediation. Hence, 
defining documentary as critical posthuman art is not to constitute a static perception of the observed at present. Concurrently, the question of who tells the posthuman narrative is not the prime concern. In problematizing whether the human should either be iterated or negated, what rises as essential is the continuous negotiation of the situated human to narrate itself in relation to everything else. The focus, then, turns to the process of mediation itself.

\section{Regenerative Documentary Ontogeny}

At the intersection of technology, documentary, and critical posthumanism, I introduce the ontogeny of regenerative documentary. The Philippines is an "underdeveloped, agrarian, pre-industrial, semi-colonial and semi-feudal" (Sison, 2014, par. 12) country. Four centuries of Spanish colonial rule followed by American colonial rule resulted in a deeply entrenched social gap between the landed oligarchy and the common Filipinos (Constantino \& Constantino, 1975, 1978). Benedict Anderson (1988) theorized this power imbalance as that of cacique democracy-a strongman politics deeply rooted the colonial history of the Philippines. Accordingly, parcels of Philippine lands were distributed by the Spanish imperial rulers to peninsulares, or pure-blooded Spaniards residing in the Philippines. The peninsulares assigned administration of these lands to local leaders. The local landlords' main task was to collect land taxes. These landlords were the same group that collaborated with the Americans as compradors in trade, economic, and political operations. They eventually rose as the comprador-landlord class. Anderson's (1988) cacique democracy outlined the domination of the local elites throughout the changing tides of history, revealing the material foundation for the formation of the Philippine oligarchy and political dynasties.

The oligarchy has monopoly ownership of, among others, the infrastructures of information communication technologies (ICT) in the Philippines. These companies are protected by obsolete telephony regulations hostile toward new ICT ventures (Valdez, 2018). As a result, the Philippines has the slowest and most expensive internet in the AsiaPacific region and globally (Barreiro, 2017) due to lack of competition and deregulation through the political and economic influence of these oligarch-owned companies. For this reason, what is considered as given in the technological evolution of interactive documentary, such as high-speed broadband in domestic households, is not present in the Philippines and in most countries in the so-called Global South.

The North-South disparity was created by the extractive colonial enterprises in the fifteenth century that left colonized countries 
"underdeveloped" (Opperman, 2018). This condition persists now as what Manuel Castells (1999) identified as the inclusion/exclusion binary logic in the current information society. In his theory of the space of flows, Castells (2000) saw the network society as a global feedback loop whose horizontal, decentralized, and asymmetrical model freed itself from the "vertical organizations that shaped the history of humankind: states, religious apparatuses, war lords, armies, bureaucracies, and their subordinates in charge of production, trade, and culture" (2004, p. 5). However, this loop was based on a "mature industrial society" (p. 5) that countries in the Global South did not have the material conditions to develop. The "time lag" (p. 5 ) in the network society feedback loop was such that the space of flows remained a unilateral transmission of power. Countries like the Philippines, for example, participate in this network mainly through low-skills enterprises such as call centers. ICT in the Philippines was mostly developed through the business processing outsourcing industry as a service sector.

The exorbitant cost of internet connectivity in the Philippines was also the reason why the Free Facebook (Murlidhar, 2010) experiment launched in the Philippines in 2015 de facto became the online portal of most Filipinos. In collaboration with existing ICT companies (Facebook \& Globe, 2015), Facebook widened its user base in developing countries through this project (Mirani, 2015). It picked the Philippines as patient zero (Pagulong \& Desiderio, 2015). The Free Facebook algorithm of inclusivity that enabled pre-cached Facebook newsfeed stories in areas with limited internet connection (Facebook news feed algorithm history | 2018 Update, 2018) was leveraged as political traction. Profit-driven telecommunications companies already in partnership with Facebook (Team Orange, 2014) were given the advantage of curating news and information to pre-cache in Facebook news feeds through their Facebook "free" usage offer (Facebook \& Globe, 2015). In the Philippines, identified as the global top internet user since 2015 (Kemp, 2015, 2016, 2017, 2018, 2019, 2020), Free Facebook was key to the rise of Rodrigo Duterte, who used the free social media platform to aggressively push his presidential campaign (Swearingen, 2018).

Current social media technologies are intrinsically unable to fully process and understand the diversity of data. Hence, giant social media platforms such as Facebook employ machine learning algorithms to make sense of our data (Facebook Research, n.d.). Machine learning is the learning and training of human and machine to manage and make meaning out of data increasingly characterized by high volume, velocity, and variety (Laney, 2001). This volume, velocity, and variety trope is called "Big Data." Machine learning that can only process Big Data translates to homogenization as an inherent working framework of the present machine learning paradigm. 
The fascistic potential in the Information Age lies in this unceasing move towards homogenization of data/affects to distil what passes as democracy (Hankey, Morrisson, \& Naik, 2018; Kabanov \& Karyagin, 2018). Within the Big Data paradigm, populist regimes such as Duterte's exploit the autopoietic feedback loop by employing highly organized trolls to maintain the image of its administration (Ong \& Cabanes, 2018; Newton, 2018; Etter, 2017). By capitalizing on quantity of the counterattack against the anti-drug war campaign, he establishes a perceived public approval of the killings that, along with data of decreasing crime rate, conditions the public.

In sum, Facebook became the "neutral" technology that seemingly provided agency to Filipinos by virtue of its being free (Murlidhar, 2010) and not owned by the oligarchy. By providing a platform for pluralities, an emergent power not from the center, such as Duterte, was given the agency to win through democratic elections. Nonetheless, these pluralities also comprise the authoritarian populism that marks the Duterte regime. As a means to protect life, he has rationalized killing alleged drug addicts with impunity. However, the victims are mostly from the most vulnerable sectors (Fernandez, Pangilinan, \& Quijano, 2019). Meanwhile, despite mounting deaths, the popularity of Duterte remains. Trolls or anonymous online users are bankrolled by the state (Ong \& Cabanes, 2018) to prop up the reputation of an administration increasingly criticized by local and international human rights organizations (Rañada, 2017; Ressa, 2016). These trolls are arguably part of the ICT ecosystem installed in the Philippines as specifically a developing country low-skills enterprise. All of these make up the emic reconstitution of limited technology as how it was developed and is being deployed in the Philippines.

Paradoxically but not surprisingly, Facebook was also the primary platform that enabled dissenting organizations like RESBAK. RESBAK was one of the first groups to condemn the drug war killings. The informal group of artists, media practitioners, and human rights advocates convened in December 2016, when the victims of extrajudicial killings breached 6,000 in less than six months (Regencia, 2016). A self-proclaimed socialist, Duterte offered Cabinet posts to the alliance of national democratic organizations upon winning the presidential elections (Tupaz, 2016). The strategic alliance between the state and the progressives constrained the movement that has championed human rights struggle in the country for decades. This, along with the general taciturn public reaction to the slaughter, was the context of "breaking the silence" led by RESBAK. This also informed the heterogenous character of the group as the volunteers span different political persuasions, including members of the national democratic organizations. All united to make a stand against the mounting drug war killings. Capitalizing on the 
accessibility and reach of Facebook as a distribution channel of works and calls to resistance, RESBAK came into being as a cyborgian alliance of varied identifications that moves through multi-platforms. Along with other local advocacy groups, RESBAK joined the phenomenon of social movements worldwide who have likewise found and thrived in the platform of social media (Castells, 2012).

Regenerative documentary is realized in this contiguity of the act of creation. It surfaces these actions as a whole in order to narrativize the connectivities that comprise the living system that is the social movement. In mapping the components that make a composite unity, regenerative documentary takes into account the contingent-the undefined and the precarious. The contingent is the primary focus as it is located at the margins of the wholeness that is the living system. It is through the contingent that transformations are possible.

\section{Contingency and Transformation}

To elucidate on the contingent in the living system, it is necessary to narrativize its ontogeny as well. The last watershed moment in both Philippine history and documentary was during another regime almost half a century ago that likewise utilized militarization and widespread human rights violation as a means to governance. During Martial Law declared by Ferdinand Marcos in 1972, thousands of Filipinos were killed and disappeared (Mijares, 1986). At the height of brutalities, a media blackout was implemented to quash public unrest (Pinlac, 2007). The gravity of the situation was so much so that government media workers formed a group by themselves and started documenting stories of human rights abuse (Tolentino, 2009). The AsiaVisions body of documentary videos in the 1980s critical of the government was a seminal point in local documentary production. Other than the sociopolitical content of its works that mirrored parallel developments in other art fields, AsiaVisions also pioneered nonhierarchical collective undertaking of the cinematic production that diverged from the auteur-oriented commercial studio system (Roque, 2018). Before AsiaVisions, documentary developed as a collateral of Philippine cinema through colonial, military, and commercial interests (Deocampo, 1994).

In a research on AsiaVisions (and another group, AlterHorizons), archivist Rosemarie Roque (2018) defined their works as Sineng Bayan or political collective filmmaking that aligns with the Philippine mass movement for democracy and freedom. However, she nuanced the nature of their works as introduction: 
Hindi man lahat ng likha ng dalawang grupo ang maituturing na direktang anyo ng Sineng Bayan, o mga pelikulang lantarang nagsusulong at umuugnay sa mga grupong causeoriented o progresibong kilusan ng mamamayan sa bansa, may puwang at may espasyo ang kasaysayan para kilalanin ang kanilang mga pagsisikap. (p. 78)

[While not all the works of the two groups cannot be identified as Sineng Bayan, or films that advance and coalesce with cause-oriented groups or the progressive national mass movement, history recognizes their efforts.]

The idea of contingent latches on to this casual observation of precarity of identity. Contingent refers to the point prior to becoming. Technology philosopher Gilbert Simondon (1992) conceptualized this condition as the pre-individual. Simondon, whose ideas influenced Maturana and Varela's autopoiesis, put forward a philosophical treatise that outlined the individual as only a "partial and relative resolution manifested in a system that contains latent potentials" (p. 300). In essence, the individual or living system is not a given. A living system is inherently transformative-through its necessary interaction with the environment and through the pre-individual nature that is a "source of future metastable states" (p. 306).

In the case of AsiaVisions, the contingent is located prior to its identification as a group aligned with the greater organized mass mobilization (Roque, 2018). Through production of sociopolitical documentaries and the subsequent scholarship on its body of works, AsiaVisions illustrated the ontogenetic process of interaction as cognition in autopoiesis. It came into being through (inter)action.

\section{Open Space Documentary and the Organizational}

Contingency is the operational framework of regenerative documentary. In RESBAK, it materialized as the network of part-time volunteers who are more often than not also part-time day job workers. The artist and advocate as a contractual worker falls under the large informal economy in the Philippines, a condition brought about by uneven economic development and the continuing "flexibilization" of formal work due to neoliberalist economic policies (Ofreneo, 2013). This informs why Facebook is the primary mediation used by RESBAK-its informal association is a function of free time and convenient socialization underpinned by increasing awareness of the drug war due to social media visibility of the violence. RESBAK was launched in Facebook by creating a page and uploading a 
videoke appropriating an iconic Philippine Christmas song (RESBAK, 2016). In place of original lyrics, calls to action against the drug war were written on placards held by people shot in spaces identified as extrajudicial killings crime scenes. The informality of the launch via social media was met by two-pronged attention-it was widely shared by citizens who were likewise critical of the killings and it was taken down by Facebook on December 23, 2016, only two days after uploading, after the video has had 36k views and 1.4k shares (Arumpac, 2016). The reason for the take-down was eventually traced to the song's licensing company, one of the biggest record labels in the country, who sent the group a cease and desist request (K. Dalena, personal communication, December 28, 2016). The fast comeback by legal threat of copyright infringement materialized regulatory systems in place in a virtual space that afforded contingency to coalesce. Ironically, this interaction also became the primary cognizance of the contingent's potential. The impasse due to governance set the boundary that defined the group as a whole.

On its second anniversary, RESBAK produced another Christmas carol videoke comprised of videos crowdsourced from overseas Filipino workers around the world (RESBAK, 2017b). Similarly, the lyrics of the original song were changed to reflect societal anxiety that traverses geographic borders, as OFWs offered solidarity from a distance. Other than videos, RESBAK also produced crowdsourced zines that compiled online submissions of artworks critical of the drug war. The autopoietic nature of a system that regenerates itself can be gleaned from this process of creation that is documentary in nature. By creating crowdsourced art from materials shared by concerned virtual citizens, these videos and zines mimic Manovich's (1999) take on Man With a Movie Camera as a coherent database configured from a database of diversity. ${ }^{6}$ These compilations of works were then uploaded back into the internet to circulate within the space that enabled their creation. By doing so, RESBAK further disseminates awareness about its advocacy. In the process, it gathers more potential affinities and, in turn, sources of materials and manpower/volunteers to sustain its processes.

However, as was already discussed with the limitation of openness in the Living Documentary, relying on Facebook or any social media platform alone is a losing battle. Facebook is a proprietary open social media platform "without rubrics to gauge the transformative affects of advocacy" (Arumpac, 2019a, p. 18). Its unknown algorithms gauge dissent as an aggregate of page data analytics. It then packages acts of resistance as products for targeted-advertising optimization visibility (Arumpac, 2019a). Therefore, online advocacies such as RESBAK on Facebook are inevitably seen and heard within a filter bubble (Pariser, 2012). To transcend this material technological parameter, what must be established is that RESBAK is only a 
component in the composite of unities that not only interact through online platforms but also move on the ground.

In an autopoietic system, the components are themselves autopoietic systems. RESBAK is only one of those nodes. It is united with other affiliations by virtue of its interactions shared by other contingent groups. In mapping the unities that comprise the living system, the relations are horizontal, multiple, and variable. The following mapping illustrates this complexity. Sandata (Sandata, n.d) is a collaborative platform initiated by urban development workers, researchers, and artists in 2017, with the aim of presenting Philippine drug war data through art. In 2018, it released a four-part podcast on the role of the barangay, or the smallest Philippine administrative division, in determining who lives and who dies in the drug war (Sandata, 2018). From data culled from this research, they wrought a 12-track hip-hop album Kolateral (Sandata, 2019), where each song is based on accounts by widows of extrajudicial killing victims. The members of Sandata are also members of Urbanismo (Urbanismo.PH, n.d), a collective of individuals and groups geared toward people-oriented urban development and design. One of Urbanismo's current projects focuses on war-torn Marawi by crowdsourcing memories of the displaced citizens of the destroyed Ground Zero as primer for community-led rehabilitation.? Although not concurrent and operationally related with the Urbanismo initiative, another group that pitched in help for Marawi was BABAI Women's Network, a coalition of feminist groups. ${ }^{8}$ In 2017, BABAI held a series of fundraising events for the internally displaced people of Marawi that included film screenings, a book launch of a compilation of essays on Marawi written by women, and a Maranao food tasting event. ${ }^{9}$ In 2020, just before the pandemic lockdown, Gantala Press (Gantala Press, n.d.), a feminist publishing press that is part of BABAI, Sandata, and RESBAK all converged in the fourth anniversary of RESBAK by holding a zine-making workshop together (RESBAK, 2020a). Organized by RESBAK, a writing workshop, with widows and orphans of the extrajudicial killing victims contacted through Sandata's network, was facilitated by Gantala Press (with its partner groups Better Living Through Xerography and Ibong Adorno). The final product was the first compilation of firsthand accounts of survival written by families affected by the drug war since its start in 2016. Like all other crowdsourced works of these groups in the past years, the zine is openly accessible online (RESBAK, 2020b).

Basic human rights is the organizational that holds together the relations of these unities as a distinct kind of composite unity. The rightsbased approach in Sandata and Urbanismo's urban development spatial studies, Gantala's feminist literary orientation, and RESBAK's political art 
all carry entrenched material histories of struggle that can be mapped as the negative of Anderson's (1988) cacique democracy. Parallel to the rise of the oligarchs was the formation of religious-political popular movements "characterised by social ferment rooted in economic and political factors" (La Viña citing Ileto, 1983). This collective consciousness led to a unity that eventually waged the 1896 revolution against the Spaniards (Ileto, 1979) and became the foundation of peasant unionizations in the 1940s that helped the US-Philippine government's war against Japanese colonizers (Kerkvliet, 1977). The persistence of this resistance continued after periods of colonization in the country, with efforts rechannelled against the Philippine state. From the time under neocolonial Philippine government whose economic and political interests did not accommodate its promise of post-war reparations to the peasant rebels (Kerkvliet, 1977); to the alliance of democratic organizations in the 1970s that rose against human rights violations and dire economic conditions set by neoliberal policies under Philippine Martial Law (Constantino \& Constantino, 1978); to the presentthe organizational is informed by social unrest and action aimed against the continuing historically embedded betrayal of the state of its mandate of serving the Filipino people.

The long-term existence of this organizational has sustained grassroots movements through which contingents like RESBAK, Sandata, and Gantala Press were able to reach specific communities with whom they create corresponding works. To illustrate, it was only through the mass organization Sining Kadamay that RESBAK was able to officially launch in 2017 in San Roque, a community hit hard during the first spate of drug war killings (RESBAK, 2017a). Sining Kadamay (SIKAD) is the cultural arm of the organization Kalipunan ng Damayang Mahihirap (Kadamay, n.d.), a well-established community network that forwards the cause of the urban poor constantly at the receiving end of demolitions and displacement. It was also through these community organizations on the ground that RESBAK was able to hold art therapy workshops in targeted communities with high extrajudicial death rate. Likewise, Gantala Press grounds its feminism on the Philippine context through vigorous community collaborations. It is currently affiliated with Rural Women Advocates (RUWA) (Rural Women Advocates-RUWA, n.d.), a volunteer group working for the interests of women peasants. With RUWA, Gantala produces books, zines, and radio plays that surface the stories of women largely historically unrepresented in the Philippine peasant struggle (F. Cura, personal communication, July 9, 2020). Meanwhile, members of Sandata were government workers whose community work continued after government service. Sandata was able to collate data for its projects through abiding collaboration with grassroots 
organizations that in turn trained communities to self-organize (M. C. Fernandez, personal communication, July 9, 2020).

Evidently, interactions among and between these contingent systems transform each other whilst keeping respective autonomies intact. This map of composite unity, made of components that regenerate through sustained production of art that is documentary in nature, reifies the theoretical model of open space documentary that "invokes collaboration, multiple iterations, decentralization and migration across media platforms and through distinct communities" (Zimmerman \& De Michiel, 2013, p. 357). Proposed by Patricia R. Zimmerman and Helen De Michiel, open space documentary was an effort to wrest away the documentary form from an authored rigid relationship between spectator/user narrative/interactivity. She borrows from Nicolas Bourriaud's (1998) concept of relational aesthetics that relied on proximity and tactility in redefining interactivity; and from the landscape design theory by Jai Sen (2010), who defined open space as an active construction through human interactions in actual spaces.

\section{Regenerative Documentary Figurations}

Nevertheless, where open space documentary mostly moves the documentary form into the physical social space, the case of the socialmedia heavy Philippines clearly calls for putting technological mediation back into the problematic. The drug war killings have been made possible indirectly by Facebook, through which Duterte campaigned and won in the 2016 presidential elections. In the same way, the initiatives of RESBAK, Sandata, and Gantala Press are also largely mediated by social media. Calls for collaboration, support, and invitation to participate are made through these online platforms, by virtue of these being free and the most accessible online platform across the social spectrum. This cyborg nature is the characteristic that situates regenerative documentary as a creature of its times.

Regenerative documentary factors in technology as a prosthesis with which the living system necessarily interacts. It is defined as posthuman art as it focuses not on the human story per se but on the technological migration of the story, where technology ranges from human language to the human use, and hence cognizance, of current digital technologies. The narrative it offers is the ontogeny of situated mediation. Therefore, the aesthetical figuration of regenerative documentary is a database of mediation.

In formal cinematic form, regenerative documentary can be illustrated by Beastmode, A Social Experiment (Amante \& Mesina, 2018) by Manuel Mesina III. In 2016, at the start of the Duterte administration, the production 
team seeded a video online of fabricated altercation between two known local actors and followed the trail of its virality. From shares in social media to national television news coverage to social media reaction to the further unfolding of the fake fight, Beastmode edited together multimodal footage that documented the ravenous consumption and circulation of misinformation and violence. The narrative ended when the actors were invited to participate in a mix martial arts fight for a throng fully convinced of the animosity between the actors. The social experiment proved that the magnitude and speed with which misinformation operates is uncontrollable (Esquire Philippines, 2018). This realization compelled the director to go on screen and participate in the narrative, in order to narrativize the contingent mediations and situate it against the larger state bank-rolled misinformation network that rationalizes the violence of the Duterte regime.

In multimedia form, the database of metadata can tell the story through movement of data. An example is my study of the virality of photojournalist Raffy Lerma's iconic Pieta photo (Arumpac, 2019b). The photo features a woman, Jennelyn Olayres, cradling the body of her dead lover killed by unidentified assailants on July 22, 2016. The man, Michael Siaron, was a pedicab driver. He was killed due to his alleged illegal drug activities. A placard near his lifeless body reads "I am a drug pusher." These placards were ubiquitous markers left by perpetrators in all of the Philippine drug war extra-judicial killings crime scenes during its first year. Siaron was one of more than 600 killed during the first six months of the drug war. The photo was first published in the mainstream media on July 24, 2016. It went viral and has since then been dubbed as Pieta, the photo that called worldwide attention to the Philippine drug war killings (Hegina, 2016, Phippen, 2016).

By chronologically mapping the virality of the photo from 2016 to 2019 through collecting metadata from websites that shared the photo, what surfaced as essential was the photographer's intervention for his work. By end of 2017, Lerma resigned from his job in a daily broadsheet as a photojournalist and joined the campaign against the drug war ( $R$. Lerma, personal communication, July 15, 2019). Pieta was shared as part of the press releases to identify him whenever he was invited to discuss his campaign. In effect, his proactivity fuelled the sustained visibility and the virality of Pieta. The story, told by photo metadata, was translated as a multimedia installation (Arumpac, 2019b).

The abovementioned examples are suggestive and not to be considered as prescriptive. What is highlighted is the availability of raw materialsincluding data in all platforms and their metadata, and the spectrum of their migrations within and among different platforms. From this mediation database, countless reconfigurations can be made as it is modular in nature. 
Because regenerative documentary assumes all data are open data, it addresses the question of copyright infringement by the purpose it serves. Regenerative documentary fully realizes its being through the purpose it serves. It is viable because it is produced primarily for non-profit educational purposes, ideally unbound by proprietary measures.

Regenerative documentary is autopoietic by virtue of the autopoietic system that generates it and which it regenerates and sustains. As such, its purpose emulates the purpose of the living system wherein it circulates. Purpose is a contested claim in autopoietic living systems, where regeneration is considered an end in itself (Maturana \& Varela, 1928). Instead, it can be gleaned at the edge of the system, where the struggle with the environment informs its teleology. Purpose is a relational function of successful autopoiesis (Thompson, 2004). It denotes understanding and through this, an emergence. RESBAK, Sandata, Gantala Press, and the spectrum of autopoietic systems all converged as a composite unity of resistance where and when human rights was curtailed by an environment of impunity, systemic poverty, and social inequality and injustice. Succinctly, the purpose of the regenerative documentary is to contribute to the resistance. It traverses various forms of technology in order to communicate to the milieu that itself is a collection of evolving living systems. Hence, it discerns that the environment has the capacity to transform, as well. This is where the contingent as pre-individual surfaces as integral. The diversity of the capacities, skills, and ontogeny that individuals carry with them to the organization pertains to potentials for structural couplings with the environment through innovative visualizations of database reconfigurations.

By exploring ways of telling where the ethical is the aesthetical, regenerative documentary seeks the most effective means of communication in the context of a developing nation straddled by the promise of the Information Age and the reality of a historically-constructed digital divide. In the process, a situated material emergence from the rigid documentary form can be realized. Where praxis is not a hypothetical but the material organizational, the fundamental aim of regenerative documentary is to identify and make known that a system of resistance exists and it is living. ${ }^{10}$

Haraway's (1991) proposal was to see genesis not from life. The ontogeny of regenerative documentary is death. This is a poignant take on Arendt's concept of natality, in which "the birth of new men and the new beginning" pertains to "the action they are capable of by virtue of being born" (Kristeva, 1999, p. 5). In regenerative documentary, the development of resistance through the political, social, artistic, and technological are all imaginings rooted not in innocence. Regenerative documentary, as critical posthuman art in the Philippines, works on the potential of providing transformational 
agency to what was stunted by brutal life, a nation of orphans ${ }^{11}$ borne of an inhuman state, capable of regeneration with the help of others. 


\section{References}

Amante, B. (Producer) \& Mesina III, M. (Director), (2018). Beastmode, A Social Experiment. [Motion Picture]. Philippines: [Logo Placeholder] Productions \& Monoxide Works.

Anderson, B. (1988), Cacique democracy in the Philippines: Origins and dreams, in: New Left Review, 169 (May/June), 3-31.

Arendt, H. (1998). The human condition (2nd ed). University of Chicago Press.

Arumpac, A. (2016, December 24) Statement: Artists Denounce RESBAK facebook page takedown [Post]. Facebook. https://www.facebook.com/ilawalastres/posts/10154053372636937

Arumpac, A. (2019a). Machine unlearning: Defining poor data through critical technical inquiry on videos uploaded in Facebook [Unpublished essay]. Goldsmiths, University of London.

Arumpac, A. (2019b). Uncountable uncounted: An ethical framework for the politicization of art in the context of the Philippine Drug War Sublime. Goldsmiths, University of London.

Backman Rogers, A., \& Ulfsdotter, B. (2018). Female agency and documentary strategies subjectivities, identity and activism. Edinburgh University Press.

Barbrook, R., \& Cameron, A. (1996). The Californian ideology. Science as Culture, 6(1), 44-72.

Barreiro Jr., V. (2017, June 1). PH has slowest average internet speed in Asia Pacific. Rappler. https:// rappler.com/technology/philippines-akamai-broadband-adoption-internet-speed-rankings

Bourriaud, N. (1998). Relational aesthetics. Les Presse Du Reel.

Braidotti, R. (2019). A theoretical framework for the critical posthumanities. Theory, Culture \& Society, 36(6), 31-61.

Castells, M. (1999). Information technology, globalization and social development [UNRISD Discussion Paper]. United National Research Institute for Social Development.

Castells, M. (2000). The rise of the network society (18th ed.). Blackwell Publishers.

Castells, M. (Ed.). (2004). The network society: A cross-cultural perspective. Edward Elgar Pub.

Castells, M. (2012). Networks of outrage and hope: Social movements in the Internet age. Polity.

Chattoo, C. B., \& Harder,W. (2018). Thestate of the documentary field:2018study ofdocumentaryprofessionals. Center for media \& social impact. https://cmsimpact.org/wp-content/uploads/2016/08/CMSIState-of-Documentary-Field-2018.pdf

Choi I. (2009) Interactive documentary: A production model for nonfiction multimedia narratives. In: Nijholt A., Reidsma D., Hondorp H. (Eds), Intelligent technologies for interactive entertainment. INTETAIN 2009. Lecture Notes of the Institute for Computer Sciences, Social Informatics and Telecommunications Engineering, vol 9. Springer. https://doi.org/10.1007/978-3-642-02315$6 \_5$

Conde, C. (2020). "Our happy family is gone." Human Rights Watch. https://www.hrw.org/ report/2020/05/28/our-happy-family-gone/impact-war-drugs-children-philippines

Constantino, R., \& Constantino, L. R. (1975). The Philippines: A past revisited : (Pre-Spanish - 1941). Author.

Constantino, R., \& Constantino, L. R. (1978) The Philippines: The continuing past. Foundation for Nationalist Studies.

Coronel, S., Padilla, M., Mora, D., \& The Stabile Center for Investigative Journalism. (2019, August 19). the uncounted dead of Duterte's drug war. The Atlantic. https://www.theatlantic.com/international/ archive/2019/08/philippines-dead-rodrigo-duterte-drug-war/595978/?fbclid=IwAR2FMo9UT-vj3 25PaEJvC22oglfvA2TjMKO18A4kVyaPiYgfXt7NBScbl5o 
Cousins, M., \& Macdonald, K. (1998). Imagining reality: The Faber book of the documentary. Faber \& Faber. Cucinelli, G., René-Véronneau, É., \& Oldford, B. (2018). Interactive documentaries and the connected viewer experience: Conversations with Katerina Cizek, Brett Gaylor, Jeff Soyk, and Florian Thalhofer. First Monday, 23(5).

Dauman, A., Lifchitz, P. (Producers), \& Rouch, J., Morin, E. (Director) (1961). Chronicle of a Summer. [Motion Picture]. France.

Deocampo, N. (1994). From revolution to revolution: The documentary movement in the Philippines. Documentary Box, 5. https://www.yidff.jp/docbox/5/box5-3-e.html

E. San Juan, J. (1998). Transforming identity in postcolonial narrative: An approach to the novels of Jessica Hagedorn. Post Identity. http://hdl.handle.net/2027/spo.pid9999.0001.201

Eleveth, R. (2015, July 31). Futurism needs more women. The Atlantic. https://www.theatlantic.com/ technology/archive/2015/07/futurism-sexism-men/400097/

Esguerra, D. J. (2020, July 3). BREAKING: Duterte signs anti-terror bill into law. Inquirer.Net. https:// newsinfo.inquirer.net/1301426/breaking-duterte-signs-anti-terror-bill-into-law

Esquire Philippines. (2018, July 25). Baron Geisler's violent feud with Kiko Matos is finally revealed as performance art. Esquire. https://www.esquiremag.ph/culture/books-and-art/what-was-barongeisler-versus-kiko-matos-all-about-a00203-20180725-Ifrm

Etter, L. (2017, December 7). Rodrigo Duterte turned Facebook into a weapon, with a little help from Facebook. Bloomberg. https://www.bloomberg.com/news/features/2017-12-07/how-rodrigoduterte-turned-facebook-into-a-weapon-with-a-little-help-from-facebook

Facebook \& Globe. (2015) Driving internet adoption in developing markets and the role of mobile carriers: A Philippine case study. [White paper]. https://www.ictworks.org/wp-content/ uploads/2016/01/2015-03-05-FB-Globe-Whitepaper.pdf

Facebook news feed algorithm history | 2018 Update. (2018, November 20). Wallaroo Media. https:// wallaroomedia.com/facebook-newsfeed-algorithm-history/

Facebook Research. (n.d.) Applying machine learning science to Facebook products. Facebook. Retrieved September 12, 2020 from https://research.fb.com/category/machine-learning/.

Fernandez, M. C. (Ica), Abas, M., Birowa, H., \& Abdullah, T. E. (2020). Children of war: A rapid needs assessment of orphans in Muslim Mindanao. The Asia Foundation. https://asiafoundation.org/wpcontent/uploads/2020/06/Children-of-War_A-Rapid-Needs-Assessment-of-Orphans-in-MuslimMindanao_Philippines_7-2.pdf

Fernandez, M., Pangilinan, A., \& Quijano, N. (2019). Examining the effects of drug-related killings on Philippine conditional cash transfer beneficiaries in Metro Manila, 2016-2017. https://doi. org/10.13140/RG.2.2.32082.91849/1

FilDocs, Inc. (2020, March). Daang Dokyu: A Festival of Philippine Documentaries. [Brochure]. Quezon City, Metro Manila :Author.

Galloway, D., McAlpine, K. B., \& Harris, P. (2007). From Michael Moore to JFK reloaded: Towards a working model of interactive documentary. Journal of Media Practice, 8(3), 325-339.

Gantala Press. (n.d.) Home. [Facebook page]. Facebook. Retrieved September 12, 2020 from https://www. facebook.com/gantalapress

Gaudenzi, S. (2013). The living documentary: From representing reality to co-creating reality in digital interactive documentary. Goldsmiths (Centre for Cultural Studies), University of London. 
GNU. (2018, February 14). GNU lesser general public license, version 2.1. Gnu.org. https://www.gnu.org/ licenses/old-licenses/lgpl-2.1.en.html

Goodnow, K. (2004, March 1). Interactive documentary. DigiMedia Conference, Cairo.

Grierson, J. (1933). The documentary producer. Cinema Quarterly, 2(1), 7-9.

Hankey, S., Morrison, J. K., \& Naik, R. (2018). Data and democracy in the digital age (p. 56). The Constitution Society. https://consoc.org.uk/wp-content/uploads/2018/07/Stephanie-Hankey-Julianne-KerrMorrison-Ravi-Naik-Data-and-Democracy-in-the-Digital-Age.pdf

Haraway, D. (1991). A Cyborg Manifesto: Science, Technology, and Socialist-Feminism in the Late Twentieth Century. Routledge.

Haraway, D. J. (2016). Staying with the trouble: Making kin in the Chthulucene. Duke University Press.

Hayles, K. (1999). How we became posthuman: Virtual bodies in cybernetics, literature, and informatics. University of Chicago Press.

Hayles, K. (2005). My mother was a computer: Digital subjects and literary texts. University of Chicago Press. Hayles, K. N., \& Burdick, A. (2002). Writing machines. The MIT Press.

Hegina, A. J. (2016, August 4). "Pietà"-like photo, PH drug war story on New York Times front page Inquirer. Net. https://globalnation.inquirer.net/142353/pieta-like-photo-ph-drug-war-story-new-yorktimes-front-page

Heidegger, M. (1977). The question concerning technology, and other essays. Garland Pub.

Ileto, R.C. (1979). Pasyon and revolution: Popular movements in the Philippines, 1840-1910. Ateneo de Manila University Press.

Josiah Macy Jr. Foundation. (1955). 1930-1955: A review of activities. Josiah Macy Jr. Foundation.

Kabanov, Y., \& Karyagin, M. (2018). Data-driven authoritarianism: Non-democracies and big data. In D. A. Alexandrov, A. V. Boukhanovsky, A. V. Chugunov, Y. Kabanov, \& O. Koltsova (Eds.), Digital transformation and global society (pp. 144-155). Springer International Publishing.

Kadamay. (n.d.) Home [Facebook page]. Facebook. Retrieved September 12, 2020 from https://www. facebook.com/kadamaynational/

Kemp, S. (2015). Digital, social \& mobile in Southeast Asia in 2015. https://wearesocial.com/special-reports/ digital-southeast-asia-2015

Kemp, S. (2016). Digital in 2016. https://wearesocial.com/special-reports/digital-in-2016

Kemp, S. (2017). Digital in 2017: Global overview. https://wearesocial.com/special-reports/digital-in2017-global-overview

Kemp, S. (2018). Digital in 2018: World's internet users pass the 4 billion mark. https://wearesocial.com/ blog/2018/01/global-digital-report-2018

Kemp, S. (2019). Digital 2019: Global Internet use accelerates. https://wearesocial.com/blog/2019/01/ digital-2019-global-internet-use-accelerates

Kerkvliet, J.B. (1977). The Huk Rebellion: A study of peasant revolt in the Philippines. University of California Press.

Kristeva, J. (2001). Hannah Arendt: Life is a narrative (F. Collins, Trans.) University of Toronto Press. (Original work published in 1941).

Laney, D. (2001, February 6). 3D data management: Controlling data volume, velocity, and variety. https:// blogs.gartner.com/doug-laney/files/2012/01/ad949-3D-Data-Management-Controlling-DataVolume-Velocity-and-Variety.pdf 
La Viña, A. M. (1983). Between structures and people: Some thoughts on the sociological underpinnings of Ileto's “Pasyon and Revolution." Philippine Sociological Review, 31(3/4), 85-92. https://www.jstor. org/stable/23898201

Lee-Brago, P. (2020, June 29). WHO: Philippines COVID-19 cases rising fastest in region. Philstar.Com. https://www.philstar.com/headlines/2020/06/29/2024339/who-philippines-covid-cases-risingfastest-region

Limos, M. A. (2020, February 18). Daang Dokyu to feature the most compelling Philippine docus in the last 100 years. Esquiremag.ph. https://www.esquiremag.ph/culture/movies-and-tv/daang-dokyufilm-festival-a00293-20200218

Luhmann, N. (2013). Introduction to systems theory (P. Gilgen, Ed.). Polity Press.

Luisi, P. L. (2003). Autopoiesis: A review and a reappraisal. Naturwissenschaften, 90(2), 49-59. https://doi. org/10.1007/s00114-002-0389-9

Malinowski, B. (1922). Argonauts of the Western Pacific. Routledge.

Manovich, L. (1999). Database as symbolic form. Convergence, 5(1), 80-99.

Maturana, H. R., \& Varela, F. (1928). Autopoiesis and cognition: The realization of the living (Softcover reprint of the original 1st ed. 1980 edition). D. Reidel Publishing Company.

Maturana, H. (1978). Biology of language: the epistemology of reality. Psychology and biology of language and thought: Essays in honour of Eric Lenneberg. M. G. and E. Lenneberg. Academic Press: 27-63.

Merez, A. (2020, March 16). Luzon under enhanced community quarantine as COVID-19 cases rise. ABSCBN News. https://news.abs-cbn.com/news/03/16/20/duterte-places-luzon-under-enhancedcommunity-quarantine-to-fight-covid-19

Mingers, J. (2006). Realising systems thinking: Knowledge and action in management science. Springer US.

Mirani, L. (2015, February 9). Millions of Facebook users have no idea they're using the internet. Quartz. https://qz.com/333313/milliions-of-facebook-users-have-no-idea-theyre-using-the-internet/

Murlidhar, S. (2010, May 18). Fast and free facebook mobile access with 0.facebook.com. Facebook. https:// web.archive.org/web/20140116060937/http://www.facebook.com/notes/facebook/fast-and-freefacebook-mobile-access-with-Ofacebookcom/391295167130

Newton, C. (2018, September 5). How autocratic governments use Facebook against their own citizens. The Verge. https://www.theverge.com/2018/9/5/17821370/facebook-libya-philippines-dutertekeyboard-warriors-troll-armies

Nichols, B. (1991). Representing reality: Issues and concepts in documentary. Indiana University Press.

Nogueira, P. (2017). Participative Interactive Documentary as a fragmented and "deterritorialized" archive. Cinergie - II Cinema e Le Altre Arti, 10, 156-164.

O'Falt, C. (2016, April 8). Full frame: Why are women filmmakers finding moreopportunities in documentaries? IndieWire. https://www.indiewire.com/2016/04/full-frame-why-are-women-filmmakers-findingmore-opportunities-in-documentaries-21750/

Office of the President. (2020, March 16). Memorandum from the Executive Secretary: Community quarantine over the entire Luzon and further guidelines for the management of the Coronavirus Disease 2019 (COVID-19) situation. https://www.officialgazette.gov.ph/downloads/2020/03mar/20200316MEMORANDUM-FROM-ES-RRD.pdf

Ofreneo, R. E. (2013). Precarious Philippines: Expanding informal sector, "flexibilizing" labor market. American Behavioral Scientist, 57(4), 420-443. 
Ong, J. C., \& Cabanes, J. (2018, February 11). Chief disinformation architects in the PH: Not exactly who you think. Rappler. http://www.rappler.com//thought-leaders/195743-disinformation-architectsphilippines

Opperman, D. (Ed.). (2018). Internet governance in the global south-history, theory and contemporary debates. International Relations Research Center Núcleo de Pesquisa em Relações Internacionais (NUPRI) University of São Paulo.

Pagulong, C. J., \& Desiderio, L. (2015, March 20). Facebook offers free internet access in Phl. PhilStar Global. https://www.philstar.com/headlines/2015/03/20/1435536/facebook-offers-free-internetaccess-phl

Pariser, E. (2012). The filter bubble: What the internet is hiding from you. Penguin.

Phippen, J. W. (2016, August 6). Can this photo end vigilante killings in the Philippines? The Atlantic. https://www.theatlantic.com/news/archive/2016/08/la-pieta-philippines-duterte/494330/

Pinlac, M. (2007). Marcos and the press. Center for Media Freedom and Responsibility. Retrieved from http://cmfr-phil.org/media-ethics-responsibility/ethics/marcos-and-the-press/

Raessens, J. (2006). Reality play: Documentary computer games beyond fact and fiction. Popular Communication, 4(3), 213-224.

Ramage, M., \& Shipp, K. (2009). Systems thinkers (2009 edition). Springer.

Rañada, P. (2017, August 3). Duterte says online defenders, trolls hired only during campaign. Rappler. http://www.rappler.com//nation/176615-duterte-online-defenders-trolls-hired-campaign

Rappler. (2016, 2018). Drug War series. Rappler. http://www.rappler.com/previousarticles?filterMeta=Drug War Series

Regencia, T. (2016, December 16). Duterte's drug war: Death toll goes past 6,000. Aljazeera.Com. https:// www.aljazeera.com/blogs/asia/2016/12/duterte-drug-war-death-toll-6000-161213132427022. html

RESBAK. (n.d.) Home [Facebook page]. Facebook. Retrieved September 12, 2020 from https://www. facebook.com/artistsresbak

RESBAK. (2016, December 21) \#HindiOke \#StoptheKillings \#RESBAK [Video]. Facebook. https://www. facebook.com/watch/?ref=search\&v=664983860351129\&external_log_id=4ed0cf20-0127-48b98b8c-18fb81153a67\&q=resbak\%20christmas\%20in\%20our\%20hearts

RESBAK (2017a, January 31) Resbak: Arawng pagkakaisa. [Photo]. Facebook. https://www.facebook.com/ artistsresbak/photos/a.674043466111835/685973234918858/

RESBAK. (2017b, December 24). HindiOke 2: Maligaya sana ang pasko (Christmas would be joyful). [Video]. Facebook. https://www.facebook.com/artistsresbak/videos/839490152900498/

RESBAK. (2020a, February 16). ATM: Sa pangunguna ng RESBAK, Gantala Press, at BLTX, isang zinemaking workshop ang ilulunsad kasama ang mga nanay at anakng mga biktima...[Photo]. Facebook. https:// www.facebook.com/artistsresbak/posts/1386008361582005

RESBAK. (2020b, March 29). As deaths due to COVID-19 rise, each victim known only by an assigned number, we remember the thousands of victims... [Facebook post]. Facebook.

Ressa, M. (2016, October 3). Propaganda war: Weaponizing the internet. Rappler. https://www.rappler. com/nation/148007-propaganda-war-weaponizing-internet

Rural Women Advocates - RUWA. (n.d.) Home [Facebook page]. Facebook. Retrieved September 12, 2020 from https://www.facebook.com/ruwaph 
Roque, R. (2018). Artsibo at sineng bayan: Pagpapanatiling kolektibong alaala at patuloy na kolektibong pagsalungat sa kasinungalingan at panunupil. Plaridel Journal, 15(2), 71-112. http://www. plarideljournal.org/article/artsibo-at-sineng-bayan-pagpapanatili-ng-kolektibong-alaala-atpatuloy-na-kolektibong-pagsalungat-sa-kasinungalingan-at-panunupil/

Sandata. (n.d.). Home [Facebook page]. Facebook. Retrieved September 12, 2020 from https://www. facebook.com/oplansandata/

Sandata. (2018, August 1). The Barangay and the Philippine drug war. [Video]. Facebook. https://www. facebook.com/artistsresbak/videos/974492659400246/

Sandata. (2019, June 29). Kolateral (Album). Beatsource. https://www.beatsource.com/release/ kolateral/390271

Sen, J. (2010). On open space: Explorations towards a vocabulary of a more open politics. Antipode, 42(4), 994-1018.

Shannon, C. E. (1948). A mathematical theory of communication. The Bell System Technical Journal, 27, 379-423, 623-656.

Simon, K. (2020). Digital 2020: 3.8 billion people use social media. https://wearesocial.com/blog/2020/01/ digital-2020-3-8-billion-people-use-social-media

Simondon, G. (1992). Incorporations. In J. Crary \& S. Kwinter (Eds.), The genesis of the individual (pp. 297319). Zone Books.

Sison, J. M. (2014, January 19). The Communist Party of the Philippines on Maoism, new democratic revolution, China \& the current world [Interview]. Jose Maria Sison. https://josemariasison.org/thecommunist-party-of-the-philippines-on-maoism-new-democratic-revolution-china-the-currentworld/

Spivak, G. C. (1993). Can the subaltern speak? L. Chrisman \& P. Williams (Eds.), Colonial discourse and postcolonial theory: A reader (pp. 66-111). Harvester Wheatsheaf.

Stallman, R. (2015). Free software free society: Selected essays of Richard M. Stallman. Free Software Foundation.

Stiegler, B. (1998). Technics and time, 1: The fault of Epimetheus (R. Beardsworth \& G. Collins, Trans.). Stanford University Press.

Swearingen, J. (2018, September 4). Facebook used the Philippines to test free Internet. Then a dictator was elected. Intelligencer. http://nymag.com/intelligencer/2018/09/how-facebooks-free-internethelped-elect-a-dictator.html

Team Orange. (2014, February 26). Facebook CEO Mark Zuckerberg: Philippines a successful test bed for Internet.org initiative with Globe Telecom partnership. Orange Magazine. https://orangemagazine. ph/2014/mark-zuckerberg-globe-telecom-partnership/

The Anti-Terrorism Act of 2020, Pub. L. No. Republic Act No. 11479 (2020). https://senate.gov.ph/ lisdata/3163229242!.pdf

The Linux Information Project (LINFO). (2006, August 6). The Unix philosophy: A brief introduction. The Linux Information Project (LINFO). http://www.linfo.org/unix_philosophy.html

Thompson, E. (2004). Life and mind: From autopoiesis to neurophenomenology. A tribute to Francisco Varela. Phenomenology and the Cognitive Sciences, 3(4), 381-398. 
Tolentino, R. (2009, January 25). Political film collectives, Introduction to ASEAC panel. Rolando Tolentino. https://rolandotolentino.wordpress.com/2009/01/25/political-film-collectives-introduction-toaseac-panel/

Tupaz, V. (2016, May 31). Leftist nominees join meeting of incoming Duterte Cabinet. Rappler. http:// www.rappler.com/nation/134871-leftist-nominees-dswd-dar-meet-duterte

Ulfsdotter, B., \& Backman Rogers, A. (2018). Female authorship and the documentary image, theory, practice and aesthetics. Edinburgh University Press.

United Nations High Commissioner for Human Rights, Office of the, \& High Commissioner and the Secretary-General. (2020). Report of the United Nations High Commissioner for Human Rights on the situation of human rights in the Philippines (Human Rights Council). https://www.ohchr.org/ Documents/Countries/PH/Philippines-HRC44-AEV.pdf

Urbanismo.PH. (n.d.). Urbanismo.Ph - Urbanisasyon para sa nakararami. O sa Ingles, making Philippine cities great (again)! https://urbanismo.ph/

Valdez, E. (2018, December 28). ICT expert lays down challenges in Philippines' digital infrastructure. PhilStar Global. https://www.philstar.com/business/2018/12/28/1880012/ict-expert-lays-downchallenges-philippines-digital-infrastructure

Vertov, D. (Director). (1927). Man With a Movie Camera.[Motion Picture]. Soviet Union: All-Ukrainian Photo Cinema Administration.

Ward, P. (2006). Documentary: The margins of reality. Columbia University Press.

Weaver, W. (1953). Recent contributions to the mathematical theory of communication. Institute of General Semantics, 10(4), 261-281.

Wiener, N. (1947, January). A scientist rebels. Atlantic monthly. http://web.cs.ucdavis.edu/ rogaway/ classes/188/materials/wiener1.pdf

Wiener, N. (1948). Cybernetics: or the control and communication in the animal and the machine. Cambridge: The MIT Press.

Winston, B. (1995). Claiming the real: The Griersonian documentary and its legitimations. British Film Institute.

Yahya, M. N. (2017, June 13). Marawi Siege, a terrorist War? Ranao Star News Online. http://ranaostar. blogspot.com/2017/06/global-war-on-terror-too-complex-for.html

Yale University. (2017, March 2). Posthuman, all too posthuman [Video]. YouTube. https://www.youtube. com/watch?v=OjxelMWLGCo

Zimmermann, P. R. \& De Michiel, H. (2013). Documentary as an open space. In B. Winston (Ed.), The documentary film book (pp. 355-365). British Film Institute.

Zylinska, J. (2014). Minimal ethics for the anthropocene. Open Humanities Press.

\section{Endnotes}

${ }^{1}$ It was only recently that a comprehensive study on woman, social media, and documentary have been pursued in earnest (Ulfsdotter \& Backman Rogers, 2018; Backman Rogers \& Ulfsdotter, 2018).

${ }^{2}$ Katherine Hayles (1999) posited four parameters of virtuality, establishing it as a condition where [1] binary pattern is more cogent than embodiment, and [2] consciousness and [3] body are but augmentations to the essential computational under physical reality. She concluded that [4] the human is a configuration that "can be seamlessly articulated with intelligent machines" (p. 2-3). 
${ }^{3}$ Case in point was Haraway's (2016) neologism sympoiesis. Haraway stated that "nothing is really autopoietic or self-organizing" and hence "sympoiesis is a word proper to complex, dynamic, responsive, situated, historical systems" (p. 58). Clearly, the complex nuanced biological definition of autopoiesis has been reduced through variations of its construed meaning over time, as systems theorists grappled to apply it to human society and in the process overdetermined it.

${ }^{4}$ According to Hayles (1999), the conferences did not require written papers from the participants/ speakers.

${ }^{5}$ Maturana and Varela (1928) defined structural coupling as the interdependence of two living systems through recurring interactions.

${ }^{6}$ Lev Manovich's (1999) observation was that the Man With A Movie Camera (Vertov, 1927) compels with its meaning-making "motivated by a particular argument, this being that the new techniques to obtain images and manipulate them" (p. 97). Manovich's interest in the film primarily lies in seeing the structure of Man With A Movie Camera as an empirical epistemological method that created a database of exciting new techniques from a database of disparate data as images.

${ }^{7}$ In the 2017 Marawi Siege, aerial bombs rained down the city to flush a small band of criminals (Yahya, 2017) causing widespread devastation and consequently, displacement of the locals. Duterte declared Martial Law through Proclamation 216 on May 23, 2017. It was only lifted on January 1, 2020, a few months before the passage of Anti-Terrorism Law.

${ }^{8}$ Babai Womens Initiative is composed of Feminista PH, Filipina Pen \& Ink, Gabriela Network of Professionals, Gantala Press, Inc., Good Food Community, Jovenes Foundation, Inc., Me \& My Veg Mouth, and Saltwater Cinema.

${ }^{9}$ The last activity was both an introduction and documentation of Maranao cuisine developed and enriched through maritime exchanges in Southern Philippines.

10 "Unless one knows which is the living organization, one cannot know which organization is living" (Maturana and Varela, 1928, p. 83).

${ }^{11}$ The plight of orphans of wars is an understudied area in the Philippines. It was only recently that comprehensive research emerged about the orphans of the Drug War (Conde, 2020) and the orphans of the Mindanao wars from 2009 to 2019 (Fernandez, et al., 2020).

ADJANI GUERRERO ARUMPAC is a documentarist and an Assistant Professor of the University of the Philippines Film Institute (UPFI). She was awarded a British Foreign and Commonwealth Office's Chevening scholarship in 2018 through which she finished her MA on Digital Media and Cultural Studies at Goldsmiths University of London. (corresponding author: adjani.arumpac@upd.edu.ph). 